\title{
ŻYCIE I DZIAŁALNOŚĆ NAUKOWA KS. DR. HAB. ZDZISŁAWA PAWLAKA, PROF. UMK
}

Ksiądz Zdzisław Pawlak urodził się 13 października 1942 roku w Joance, pow. Kalisz. Po maturze (1960 r., Liceum Ogólnokształcące im. A. Asnyka w Kaliszu) wstąpił do Wyższego Seminarium Duchownego we Włocławku. Tutaj zdobył podstawową formację intelektualną w zakresie filozofii i teologii. Jego profesorem był m.in. ks. prof. dr hab. Józef Iwanicki (teoria poznania, psychologia, filozofia przyrody), któremu zawdzięcza swoje pierwsze zainteresowania filozofią. Podczas studiów seminaryjnych był na seminarium naukowym z teologii dogmatycznej (nie było wówczas seminarium z filozofii), gdzie napisał pracę dyplomową pt. Nauka św. Tomasza o pochodzeniu Osób Boskich. Święcenia kapłańskie otrzymał 17 czerwca 1966 roku w katedrze włocławskiej.

Po dwóch latach pracy na wikariacie w Gosławicach k. Konina (1966-1968) bp A. Pawłowski skierował go na studia specjalistyczne z teologii fundamentalnej. Na własną prośbę otrzymał dekret zmieniający kierunek i pozwalający na studia w sekcji filozofii teoretycznej na Wy-

* Ks. prof. dr hab. Krzysztof Konecki jest kierownikiem Zakładu Liturgii na Uniwersytecie Mikołaja Kopernika w Toruniu; twórca i redaktor naczelny czasopisma „Teologia i Człowiek”. 
dziale Filozofii Chrześcijańskiej KUL. Tutaj na seminarium naukowym z metafizyki, prowadzonym przez o. prof. dr. hab. M. A. Krąpca, napisał pracę magisterską nt. „Problem apofatycznego poznania Absolutu w Sumie teologii Tomasza z Akwinu" (1971). Trzeba dodać, że ks. Z. Pawlak, studiując w tym czasie na Wydziale Filozofii Chrześcijańskiej KUL, miał niezwykłe szczęście. Jego bowiem profesorami (prawdziwie wielkimi mistrzami uniwersyteckimi filozofii) byli: Stefan Swieżawski, Mieczysław Albert Krąpiec, Stanisław Kamiński, Karol Wojtyła, Mieczysław Gogacz, Marian Kurdziałek, Antoni Stępień, Zofia Józefa Zdybicka, Stanisław Kowalczyk. Większość z nich to współtwórcy znanej w Polsce i na świecie Lubelskiej Szkoły Filozoficznej.

Stopień naukowy doktora filozofii uzyskał w 1974 roku na podstawie rozprawy: Filozoficzne implikacje poglądów Mircei Eliadego na strukturę religii, pisanej również na seminarium o. prof. dr. hab. M. A. Krąpca (promotorem była s. prof. dr. hab. Z. J. Zdybicka).

Uwieńczeniem filozoficznych badań na polu filozofii religii, a poświęconych koncepcji religii Eliadego jest wydana pozycja książkowa pt. Filozoficzna interpretacja koncepcji religii Mircei Eliadego (Włocławek 1995, ss. 232). Jest ona, w porównaniu z pracą doktorską opartą na bibliografii tylko do roku 1973, studium bardziej poszerzonym i pogłębionym (zwłaszcza o elementy krytyczne), uwzględniającym również późniejsze prace Eliadego (wydawane przez niego do momentu śmierci - 22.04.1986), np. m.in. wielkie, trzytomowe dzieło Histoire des croyances et des idées religieuses (wydane także w Polsce pt. Historia wierzeń $i$ idei religijnych). W książce obok pozycji Eliadego (wydawanych szczególnie u nas w Polsce w latach dziewięćdziesiątych) ks. Pawlak wykorzystał także opracowania z literatury pomocniczej do roku 1994. Pozycja ta jest cennym wkładem w rozwój polskiej myśli religioznawczej, a przede wszystkim dobrze orientującym studium w filozoficznej koncepcji religii u Mircei Eliadego.

Powrót do diecezji ks. dr. Pawlaka, po studiach filozoficznych w Lublinie uwieńczonych doktoratem, niestety, nie sprzyjał owocnej pracy naukowej. Przez siedem bowiem lat był wikariuszem (na pełnym etacie) w dwóch parafiach włocławskich, dochodząc z wykładami (początkowo z metafizyki i teorii poznania, później cała historia filozofii, etyka i filozofia Boga) do Seminarium Duchownego. Był w tym czasie również przez kilka lat organizatorem i prowadzącym kursy przedmałżeńskie dla Włocławka, dwukrotnie referentem ds. KUL i TPKUL oraz przez sześć lat diecezjalnym duszpasterzem akademickim z normalnymi zajęciami (dwa razy w tygodniu) dla młodzieży szkół pomaturalnych. Mimo wielu 
próśb składanych do bpa J. Zaręby o zwolnienie przynajmniej z obowiązków wikariusza parafii, sytuacja ta trwała do 1980 roku. W tym czasie udało mu się wyjechać (dwa razy) na wakacyjne stypendia językowe (lipiec-sierpień 1977 - Goethe-Institut w Rothenburu; lipiec-sierpień 1980 - Goethe-Institut w Passau); później, już po odejściu z wikariatu, otrzymał roczne stypendium językowe do Rzymu (1984-1985) z pobytem w Instytucie Polskim.

Warunki do pracy naukowej zmieniły się nieco po wyjściu z pracy duszpasterskiej na parafii. Obok jednak wykładów w Seminarium Duchownym we Włocławku doszły inne obowiązki: zorganizowanie diecezjalnego oddziału TP KUL i jego biura we Włocławku oraz wyjazdy do parafii z akcjami na rzecz KUL-u (przez prawie osiem lat był w 139 parafiach naszej diecezji), przez sześć lat był także diecezjalnym duszpasterzem inteligencji (organizowanie spotkań, głoszenie prelekcji dla inteligencji Włocławka). Przez szereg lat pełnił także funkcję penitencjarza katedralnego oraz przez 16 lat był spowiednikiem zwyczajnym Sióstr Wspólnej Pracy od Niepokalanej Maryi.

Mimo tego typu różnorakich obowiązków, które pochłaniały sporo czasu, ks. dr Z. Pawlak starał się jednak nie zaniedbywać pracy naukowej, wykorzystując, na ile to było możliwe, każdy wolny czas. Owocem jego wysiłków jest dorobek naukowy, który do czasu habilitacji oprócz wymienianej pozycji książkowej obejmuje: 22 artykuły naukowe (w pracach zbiorowych i czasopismach), 11 artykułów popularnych, 31 recenzji, 3 sprawozdania, 2 wywiady, nie licząc współautorstwa działu w „Ateneum Kapłańskim” (wraz z ks. K. Koneckim): Człowieka nie można do końca zrozumieć bez Chrystusa (AK w latach 1990-1995) oraz tekstów o różnorodnej tematyce zamieszczanych $\mathrm{w}$ pracach zbiorowych czy czasopismach. Publikacje te dotyczyły głównie problematyki z zakresu: metafizyki, filozofii Boga, filozofii religii, etyki i filozofii polskiej.

Uwieńczeniem dotychczasowego dorobku naukowego ks. dr Pawlaka jest rozprawa habilitacyjna Neoscholastyka i formy jej kontynuacji. Studium analityczno-krytyczne twórczości filozofów włocławskich XX wieku. Problematyką dotyczącą tej pracy zajmował się on już od kilku lat. Podstawą dla przeprowadzenia analiz badawczych stała się twórczość naukowo-filozoficzna czterech profesorów: ks. Idziego Radziszewskiego (1871-1922) - rektora trzech uczelni, ks. Adama Jankowskiego (1884-1949), ks. Józefa Iwanickiego (1902 - 1995) - rektora dwóch uczelni i ks. Stanisława Mazierskiego (1915-1993), wywodzących się ze środowiska włocławskiego (stąd termin "filozofowie włocławscy"). 
Używając określenia "filozofowie włocławscy”, ks. Pawlak ma na myśli czołowych przedstawicieli środowiska naukowo-filozoficznego Wyższego Seminarium Duchownego we Włocławku w okresie międzywojennym, którzy w większości byli również znanymi profesorami uczelni uniwersyteckich czy nawet rektorami tychże uczelni oraz organizatorami życia naukowego. To właśnie dzięki nim włocławskie seminarium duchowne, szczególnie w I połowie XX wieku było tak znane i cenione w Polsce, zajmując wysoką pozycję wśród uczelni tego typu i posiadając przyznane uchwałą Rady Ministrów (z dnia 17.10.1927 r.) prawa szkoły wyższej, równoznaczne z fakultetami teologicznymi na uniwersytetach. Filozofowie włocławscy XX wieku (przeważnie absolwenci renomowanych uczelni zagranicznych) przez swoje publikacje naukowe $\mathrm{w}$ postaci poważnych dzieł, rozpraw, artykułów i innych pozycji naukowych oraz swoją działalnością naukowo-dydaktyczną i organizacyjną na wyższych uczelniach, przyczyniali się do umacniania, rozwijania i szerzenia ruchu neoscholastycznego, zwłaszcza myśli neotomistycznej (w różnej postaci) w Polsce. Ich działalność i dorobek naukowy to pokaźny i trwały wkład nie tylko do filozofii neoscholastycznej, ale również do współczesnej filozofii polskiej.

Celem rozprawy habilitacyjnej ks. Pawlaka była nie sama rekonstrukcja i wierne przedstawienie poglądów filozoficznych tychże myślicieli, ale także ukazanie ich genezy, uwarunkowań oraz ocena krytyczna płynąca z porównania ze stanowiskami innych współczesnych autorów, a nawet $\mathrm{z}$ koncepcjami dzisiejszymi. Zadanie podjęte $\mathrm{w}$ tej pracy nie było więc łatwe do wykonania. Trzeba było bowiem prześledzić cztery różne (sprowadzone ostatecznie do trzech) - wyrosłe po części z tego samego źródła - style myślenia filozoficznego, konstytuujące poszczególne formy kontynuacji neoscholastyki.

Główny problem pracy sprowadzał się zasadniczo do odpowiedzi na następujące pytania: 1) czy twórczość filozofów włocławskich XX wieku można określić mianem neoscholastycznej i dlaczego?, 2) jaką formę neoscholastyki prezentują filozofowie włocławscy?, 3) czy jest to tylko przeniesienie z Zachodu i upowszechnienie neoscholastycznego sposobu filozofowania, czy raczej twórcza asymilacja, a może nawet własne oryginalne podejście?, 4) co wnieśli filozofowie włocławscy do polskiej neoscholastyki?, 5) jakie jest znaczenie ich wkładu do historii polskiej kultury filozoficznej? Przedstawione powyższe kwestie starała się rozwiązać ta rozprawa, złożona $\mathrm{z}$ trzech części (są to zarazem prezentacje trzech różnych form kontynuacji neoscholastyki). W rezultacie powstał w miarę 
całościowy obraz twórczego dzieła włocławskich neoscholastyków XX wieku. Wszyscy oni bowiem realizowali (każdy w charakterystyczny dla siebie sposób) główne idee, hasła oraz wytyczne ruchu neoscholastycznego.

Kolokwium habilitacyjne ks. Pawlaka odbyło się 3 lipca 2001 roku na Katolickim Uniwersytecie Lubelskim. Recenzentami byli: ks. bp prof. dr hab. B. Dembowski (UKSW), s. prof. dr hab. Z. J. Zdybicka (KUL) i prof. dr hab. W. Tyburski (UMK). Habilitacja została zatwierdzona 17 grudnia 2001 roku przez Centralną Komisję do Spraw Tytułu Naukowego i Stopni Naukowych w Warszawie.

Pracę naukowo-dydaktyczną ks. prof. Z. Pawlak rozpoczął we wrześniu 1974 roku, podejmując wykłady w Wyższym Seminarium Duchownym we Włocławku. Wykłada do dziś (38 lat) następujące przedmioty: metafizykę, historię filozofii, filozofię Boga, teorię poznania i etykę). Prowadzi także wykłady w Instytucie Teologiczno-Pastoralnym dla księży (1974-1990) oraz dla osób świeckich, najpierw na Instytucie Wyższej Kultury Religijnej we Włocławku (był również zastępcą dyrektora tegoż Instytutu), a od 1990 roku wykłady (metafizyka, teoria poznania, historia filozofii, filozofia Boga, etyka) na Studium Teologii we Włocławku (filia Papieskiego Wydziału Teologicznego w Warszawie). W latach 1983-1994 prowadził wykłady (filozofia Boga, ogólna metodologia nauk) w Seminarium Duchownym Księży Misjonarzy w Bydgoszczy, w latach 1994-1998 w Seminarium Duchownym w Toruniu (metafizyka, filozofia Boga) oraz wykłady (historia filozofii, metafizyka, filozofia Boga, etyka) na Kolegium Katechetycznym w Kaliszu (1988-1999). Od 1995 do 2001 roku na Wydziale Ekonomii i Wydziale Pedagogiki i Pracy Socjalnej Wyższej Szkoły Humanistyczno-Ekonomicznej we Włocławku (podstawy filozofii, filozofia z logiką, etyka - zarówno dla studentów dziennych, jak i zaocznych).

Ksiądz prof. Z. Pawlak jest założycielem (listopad 1988) Koła Filozoficznego we włocławskim Wyższym Seminarium Duchownym, które wspierało i w jakimś stopniu uzupełniało przez swoją wieloletnią działalność nauczanie filozofii. Było ono kontynuacją nieformalnych spotkań filozoficznych podejmowanych we włocławskim seminarium duchownym w końcu XIX i na początku XX wieku przez ówczesnych profesorów filozofii ks. Idziego Radziszewskiego (Schola Aegidiana) i ks. Adama Jankowskiego (Collegium Philosophicum), a także prowadzonego przez niego przez kilka lat seminarium naukowego z filozofii.

Ksiądz Z. Pawlak ma współudział, jako członek założyciel, w powstaniu klubu naukowo dyskusyjnego „Krąg” (przekształconego później w Towarzystwo Naukowe Wyższego Seminarium Duchownego we 
Włocławku); w latach 1979-1984 był sekretarzem naukowym „Kręgu”, a w latach 1994-1997 pełnił funkcję prezesa tegoż Towarzystwa (na spotkaniach „Kręgu”, a później Towarzystwa wygłosił trzynaście referatów).

Od 1979 roku należy do Società Internazionale Tommaso d'Aquino, a od 1981 roku jest również członkiem zwyczajnym Włocławskiego Towarzystwa Naukowego, a od 2005 jest także członkiem zwyczajnym Towarzystwa Naukowego w Toruniu.

W latach 1990-2004 pracował w redakcji „Ateneum Kapłańskiego", a od 1997 do 2004 był zastępcą redaktora naczelnego. Jest również członkiem zespołu redakcyjnego „Studiów Włocławskich”. Od roku 2001 do 2004 sprawował funkcję rektora Wyższego Seminarium Duchownego we Włocławku.

Gdy w 2001 roku powstał Wydział Teologiczny na UMK w Toruniu, ks. dr hab. Z. Pawlak podjął się jako adiunkt w Zakładzie Filozofii Chrześcijańskiej wykładów przedmiotów filozoficznych. Od 2004 roku jest profesorem nadzwyczajnym UMK. Warto podkreślić, że ks. prof. Z. Pawlak jest autorem szeregu opracowań przygotowanych na potrzeby pracy edukacyjnej (skrypty z zakresu historii filozofii, metafizyki, filozofii Boga, teorii poznania, etyki). Był również organizatorem i aktywnym uczestnikiem wielu konferencji naukowych. W latach 2001-2004 organizował jako rektor tzw. wykłady otwarte w Wyższym Seminarium Duchownym we Włocławku. Uczestniczył niemal we wszystkich Tygodniach Filozoficznych na KUL, biorąc w nich czynny udział jako autor głoszonych referatów, czy zabierając głos w dyskusji. Od szeregu lat ks. prof. Pawlak jest także członkiem rad programowych i kolegiów redakcyjnych różnych czasopism. Współpracował także przy redakcji poszczególnych tomów Powszechnej Encyklopedii Filozofii i Encyklopedii Filozofii Polskiej (wydawanych przez Polskie Towarzystwo Tomasza z Akwinu). Był wielokrotnie recenzentem prac doktorskich (10) bronionych na KUL i Papieskim Wydziale Teologicznym we Wrocławiu.

Długoletnia praca naukowo-dydaktyczna ks. profesora Z. Pawlaka na różnych uczelniach, na stanowisku wykładowcy większości przedmiotów filozoficznych, zaowocowała dość pokaźnym dorobkiem naukowym. Jest on autorem przeszło 150 publikacji (książki, udział w pracach zbiorowych, artykuły: naukowe (około 50) i popularyzatorskie, hasła do encyklopedii i słowników biograficznych, recenzje, sprawozdania, wywiady). Jego zainteresowania naukowo-badawcze dotyczą zasadniczo dwóch płaszczyzn problemowych: jedną jest refleksja dotycząca problematyki filozofii Boga, filozofii religii, etyki i antropologii filozoficznej, a drugą - 
zainteresowania historyczno-filozoficzne dotyczące $X X$-wiecznej historii filozofii polskiej, szczególnie dziejów neoscholastyki i jej recepcji w Polsce.

Działalność naukowo-badawcza ks. prof. Pawlaka po habilitacji koncentruje się $\mathrm{w}$ dalszym ciągu na neoscholastyce $\mathrm{w}$ wydaniu tzw. filozofów włocławskich (których poglądów filozoficznych nie analizował w dotychczasowych pracach, a zasługują na takowe opracowania). Jest to analiza twórczości filozoficznej Stanisława Gruchalskiego (1872-1936), Wiktora Potempy (1887-1942), Władysława Gisztera (1898-1974) i Antoniego Warmuza (1914-1981). Nawiązywali oni również do koncepcji dawnych mistrzów filozofii średniowiecza, zwłaszcza Tomasza z Akwinu w powiązaniu ze współczesnymi sobie głównymi tendencjami badań filozoficznych.

Zajęcie się „włocławskimi neoscholastykami” i ich twórczością filozoficzną zostało u ks. prof. Pawlaka spowodowane nie tylko pragnieniem ukazania ich wkładu oraz środowiska naukowego, z którego wyszli w dzieło neoscholastyki polskiej, ale przede wszystkim brakiem tak ujętego ich całościowego opracowania, jak również brakiem opracowań bardziej szczegółowych poszczególnych postaci od strony analizy ich poglądów filozoficznych.

Należy tu podkreślić, że podjęcie się przez ks. Pawlaka zadania rekonstrukcji i krytycznego przedstawienia poglądów wybranych znaczących przedstawicieli filozofii neoscholastycznej XX wieku jest bardzo na czasie i w pełni uzasadnione. Dzieje bowiem filozofii neoscholastycznej w Polsce są ciągle terenem mało zbadanym i jak dotychczas niedostatecznie jeszcze opracowanym. Dlatego prace badawcze ks. Pawlaka są znaczącym przyczynkiem do badań nad najnowszą historią polskiej filozofii. Ich wartość widać zwłaszcza w tym, że ks. Pawlak dokonuje nie tylko adekwatnej rekonstrukcji poglądów filozoficznych wybranych myślicieli, ale ukazuje trafnie genezę i kontekst ich filozofowania. Ich poglądy potrafił nie tylko źródłowo wyeksplikować, ale zdobył się także na ich krytyczną ocenę i porównanie ze stanowiskami innych współczesnych myślicieli, a także z dzisiejszymi ujęciami rozważanych przez nich problemów.

Trzeba również zasygnalizować, że ks. prof. Pawlak przygotowuje monografię o nauczaniu filozofii w Wyższym Seminarium Duchownym we Włocławku w ciągu dziejów (od założenia w 1569 do dziś).

W ostatnich latach ks. prof. Pawlak zajął się także antropologią filozoficzną Karola Wojtyły. Prace te zaowocowały opublikowanymi wieloma artykułami (11). Warto tutaj podkreślić aktualność tych ostatnich 
prac badawczych ks. Pawlaka. W czasach bowiem obecnego duchowego i intelektualnego zagubienia człowieka, bardzo często pytamy: kim jest człowiek? Na to zasadnicze pytanie przynosi głęboką i pełną odpowiedź antropologia adekwatna K. Wojtyły, czyli jego filozofia osoby ludzkiej. Z filozoficznego punktu widzenia, teoria ta stanowi jedną z najważniejszych koncepcji człowieka, nie tylko w filozofii polskiej, ale także w całej dotychczasowej myśli antropologicznej i jest punktem wyjścia do zrozumienia człowieka XXI wieku.

Podsumowując całość dorobku naukowego ks. dr hab. Z. Pawlaka, należy podkreślić, że jest on nie tylko bogaty i różnorodny, ale również solidny o znaczących walorach merytorycznych. Jak wynika z lektury jego publikacji, odznaczają się one rzetelnością naukową, dojrzałością w formie i treści, a także zredagowane zostały $\mathrm{w}$ fachowym i jednocześnie dostępnym języku filozoficznym. Ponadto na uwagę zasługuje aktualność podejmowanych kwestii i umiejętne włączanie się w dyskusje z zakresu problematyki filozoficznej.

Ksiądz prof. Z. Pawlak może się poszczycić wieloma odznaczeniami, wyróżnieniami i nagrodami zarówno kościelnymi, jak i uniwersyteckimi. Kolejni biskupi włocławscy, dostrzegając jego pracę duszpasterską, kapłańską postawę oraz długoletnią pracę naukowo-dydaktyczną, zwłaszcza w Wyższym Seminarium Duchownym we Włocławku, jako wyraz uznania odznaczyli go godnością kapelana papieskiego (18.02.1992), oraz włączeniem do Włocławskiej Kapituły Katedralnej jako kanonika gremialnego (19.12.2001). Również na Uniwersytecie Mikołaja Kopernika w Toruniu, ks. prof. Pawlak w ciągu minionych lat, kilkakrotnie otrzymywał wyróżnienia i nagrody rektora UMK za osiągnięcia uzyskane w działalności naukowej oraz w działalności naukowo-badawczej (łącznie z nagrodami jubileuszowymi za 30 oraz 35 lat pracy naukowo-dydaktycznej). Ostatnio zaś został mu przyznany przez prezydenta RP srebrny krzyż zasługi (19.02.2012).

Szczególnym wyrazem uznania dla pracy naukowej ks. prof. Z. Pawlaka na polu filozofii jest wybranie go na wiceprzewodniczącego Sekcji Filozoficznej Wykładowców Filozofii Uczelni Katolickich w Polsce (KUL 2009 r.) 